\title{
Letter from the Editor-in-Chief
}

Peter G. M. de Jong ${ }^{1}$

Published online: 9 September 2021

(C) International Association of Medical Science Educators 2021

Welcome to the fifth issue of Medical Science Educator of 2021. The current issue features a number of manuscripts reporting on medical education, which I hope will be of interest to you.

On behalf of the entire Editorial Board, I am very pleased to announce that recently the journal has been included in PubMed Central. This is an important step forward to make our journal even more accessible for our readership. Medical Science Educator is now abstracted in 15 indexing services and available to educators in almost 7500 institutions all over the world.

We are also very pleased to see that many of our readers offer their services as a reviewer. Still we are always looking for more colleagues who would like to become part of our reviewer team. To support our reviewers in their job as reviewer, the Editorial Board is offering reviewer workshops at the IAMSE Annual Meeting and also in an online format during the year. In this way, we hope to contribute to the reviewer's professional development and to increase the quality of our peer review process. So if you want to join us in assisting in this important endeavor, please let us know by email to journal@iamse.org as we highly appreciate your help!

I hope you will enjoy this issue and that you will continue supporting Medical Science Educator both as a reader and as an author of your own scholarly work for the benefit of our work and the work of others!

Peter G.M. de Jong, PhD

Editor-in-Chief

Publisher's Note Springer Nature remains neutral with regard to jurisdictional claims in published maps and institutional affiliations.
Peter G. M. de Jong

p.g.m.de_jong@lumc.nl

1 Leiden University Medical Center, Leiden, The Netherlands 